Synthesis

\title{
Aboriginal Peoples and Forest Certification: a Review of the Canadian Situation
}

\author{
$\underline{\text { Anna V. Tikina }}^{1}, \underline{\text { John L. Innes }}^{1}, \underline{\text { Ronald L. Trosper }}^{1}$, and Bruce C. Larson $^{1}$
}

\begin{abstract}
We assess how different certification standards address Aboriginal issues in Canada, augmenting current legislation related to Aboriginal issues. The benefits from forest certification and the obstacles to its adoption by the Aboriginal community are also reviewed. We conclude that it would take significant effort, time, and resources to achieve widespread Aboriginal adoption of forest certification.
\end{abstract}

Key Words: First Nations; Aboriginal forestry; Aboriginal peoples; Canada; forest certification

\section{INTRODUCTION}

Certification of forest management has become a global phenomenon that is rapidly becoming accepted as a part of "doing business." Initially designed to combat deforestation and forest degradation in developing countries, forestcertification uptake in this area has been very slow, and the extent of certified forest in the tropics remains negligible (International Tropical Timber Organization 2005). In contrast, uptake in developed countries has been extensive, with Canada leading the world in the total area of certified forest and in the proportion of its managed forest that has been certified. Most of this certification has been for large industrial companies, and uptake by small-scale private operations and by communities has been much more limited. Three major performance-based certification systems are usually included in any discussion of sustainable forest management (SFM) certification in Canada. They are the multiple regional Forest Stewardship Council (FSC) standards, the Canadian Standards Association (CSA) Z809 standard, and the Sustainable Forestry Initiative standard (SFI).

At its conception in the mid-1990s, one of the major aims of the forest certification process has been to improve the lives of Aboriginal communities that depend on the forest (see, for example, the FSC Pr inciples and Criteria). Few certification standards explicitly focus on communal or Aboriginal forest companies, but in regions where such management is becoming more common, this option is sometimes included in the relevant standard (e.g., the draft of the 2008 FSC Australia National Standard, Indicators 3.1.1.-3.1.4.). Although most articles and reports on SFM mention the role that forest certification could play in moving a management operation towards sustainability, less attention has been given to the benefits that certification has brought to Aboriginal communities. We analyze the current state of knowledge on the relationship between certification and the livelihoods of Aboriginal peoples in Canada, and provides the background for a more detailed study of Aboriginal perspectives on forest certification. We discuss both ways in which forest certification is applicable to Aboriginal communities: (1) certification of Aboriginal forestry, and (2) certification of forest companies working in Aboriginal traditional territories. For our purposes, "traditional territory" is defined as the "land occupied and used historically" by an Aboriginal group, that is "integral to their identity and survival as a distinct nation" (British Columbia Treaty Commission 2009a).

\section{METHODS}

Our objective was to collect the evidence about the effects of forest certification on Aboriginal livelihoods, and also about the perceptions of Aboriginal peoples on forest certification in Canada. The review methodology included a 
keyword search (keywords used: forest certification, Aboriginal people, First Nations, criteria and indicators, Aboriginal forestry, and social issues and impacts), and a search of authors who have written on the topic of Aboriginal forestry or legal aspects of resource management in Canada. Expert advice was also used to identify primary references on the topic and the names of researchers working in the area. The sources were peer-reviewed publications including books or articles published in scientific journals, and "gray" literature, including on-line reports or popular articles that have not been reviewed by independent peers. The references in the found sources were checked for related information, and "related article" searches were also included in the data collection. Overall, more than 100 sources were identified. The search was limited to publications in English.

During the search, the research questions were refined to reflect the applicability of specific standards and legal requirements, and Aboriginal sources in favor or critical of forest certification. The collected information was evaluated based on its relevance to the topic (Cooper 1998). For example, the list of the court cases was limited to cases dealing with resource management. Once the relevant sources were identified, the available information was analyzed using the review questions described above.

\section{HOW THE STANDARDS ADDRESS ABORIGINAL ISSUES}

Smith (1998) calls for the recognition of Aboriginal rights and title as an aspect of SFM. Forest certification standards differ on how they address Aboriginal peoples' rights and issues. As all standards under review require compliance with applicable laws and regulations, a brief review of the main regulatory milestones pertaining to Aboriginal issues follows. We include an analysis of how each of the forest certification systems approach Aboriginal issues.

\section{Applicable Laws and Regulations}

Three levels of legislation are applicable in Canada: international agreements ratified by the country, federal legislation, and documents adopted at the provincial or territorial level. Whereas the first two sets of documents regulate activities across the country, provincial laws and regulations differ in their approaches to Aboriginal issues (Tollesfon et al. 2008). Although earlier provincial documents seem to undermine the inclusion of Aboriginal cultural values into forest management, more recent developments show that almost all provinces and territories provide for inclusion of cultural information into forest management planning (Elias 2004). The duty to consult with Aboriginal groups has been reflected in a greater number of legal and regulatory sources, and provinces or territories make steps of varying effectiveness toward interweaving Aboriginal values in forest management (Elias 2004, McGregor 2009). As Canadian law is also based on precedent, court decisions, and especially those of the Supreme Court of Canada, constitute a significant source of regulation.

Canada has not signed the UN Declaration on the Rights of Indigenous Peoples (United Nations 2007), but has ratified some of the applicable human-rights international conventions (Table 1). The Canadian definition of Aboriginal rights and title includes the following statement: "Aboriginal rights refer to practices, traditions and customs that distinguish the unique culture of each First Nation and were practised prior to European contact. Aboriginal title is an Aboriginal property right to land." (British Columbia Treaty Commission 2008).

Canadian law dealing with Aboriginal peoples is evolving rapidly, and the interpretation of that law is constantly changing with the case law introduced by court decisions. For example, the Gitanyow decision of the British Columbia Supreme Court (Canadian Legal Information Institute 2004c) rules for "deep consultation" from the side of the Crown and reconciliation of pre-existing forest licenses can be disputed, as the Crown has already issued a notice to appeal the Gitanyow decision (O'Callaghan et al. 2008). Its outcome may change with the decision of higher courts (the British Columbia Court of Appeal and, as an ultimate possibility, the Supreme Court of Canada).

\section{Forest Stewardship Council}

The four regional FSC standards in Canada (British Columbia, Boreal, Maritime, and a draft Great Lakes-St. Laurence standard) all provide specific 


\section{Table 1. Major documents related to Canadian Aboriginal law.}

International Agreements ratified by Canada

International Convention on the Elimination of All Forms of Racial Discrimination 1970 (Office of the United Nations High Commissioner for Human Rights 1969)
The Convention requires all signatory states to "take effective measures to review governmental, national and local policies, and to amend, rescind or nullify any laws and regulations which have the effect of creating or perpetuating racial discrimination wherever it exists." In the view of many First Nations, the policy that Aboriginal title needs to be proved violates the requirements of this convention (First Nations Leadership Council 2007). Examples of cases dealing with racial discrimination of Aboriginal peoples include McKinnon v. Ontario 2004 (Hadibhai 2004) and Frank v. A. J.R. Enterprises Ltd. 1993 (Ontario Human Rights Commission 2001).

Article 1 of the Covenants demands self-determination of all peoples, which applies to International Covenant on Civil and Political Rights 1976 Office of the United Nations High Commissioner for Human Rights 1976a); the determination of the political and institutional status and the pursuit of economic, social, and cultural development. Although official Canadian reports to the United Nations do not include discussion of Article 1 (Government of Canada 2004), First and Cultural Rights 1976 (Office of the United Nations have focused on the need to establish Aboriginal governments and to develop Nations High Commissioner for Human Rights $1976 b)$

UN Convention on Biological Diversity 1992 (Secretariat of the Convention on Biological Diversity 1993)

Federal Legislation

Royal Proclamation 1763 (Virtual Law Office 1998)

Constitution Act 1867 (Canadian Legal Information Institute 1867)

Constitution Act 1982, Section 35 (Canadian Legal Information Institute 1982)

Indian Act 1985 (Canadian Legal Information Institute 1985)

\section{Court Cases}

Jim 191526 C.C.C. 236 (Resources for Aboriginal Studies 2006)

Calder [1973] S.C.R. 313, [1973] 4 W.W.R. (Canadian Legal Information Institute 1973)

Kruger and Manuel [1978] 1 S.C.R. 104. (Canadian Legal Information Institute 1978)

Haines [1981] 495 BCCA (Canadian Legal Information Institute 1981)

Guerin [1984] 2 S.C.R. 335 (Canadian Legal Information Institute 1984) an independent legal system to regulate land, resources, and culture, which falls under the notion of Article 1.

Article 8(j) requires respecting, preserving, and maintaining "knowledge, innovations, and practices of indigenous and local communities embodying traditional lifestyles relevant for the conservation and sustainable use of biological diversity." The Article further demands "approval and involvement of the holders of such knowledge, innovations and practices" and suggests fair sharing of the benefits arising from the utilization of such knowledge.

Treaties between the British Crown and Aboriginal peoples are a method of extinguishing Aboriginal title to the land. The Crown has fiduciary duty for the land under the treaty.

Canadian Confederation deals with, and has obligation to legislate on, matters of Aboriginal peoples and "land reserved for Indians."

The section recognized and affirms existing Aboriginal and treaty rights. The Section applies to all Aboriginal people, including Metis, as was upheld in Powley, SCC 2003 (Canadian Legal Information Institute 2003).

Provides rules on Indian status and management of reserve lands. Although the Act presents some provisions for local governance and communal collection of monies, it has so far failed to address the issue of self-government.

Hunting and fishing on reserves are regulated by federal, rather than provincial, legislation.

The Supreme Court held that Aboriginal title exists as a concept of common law. It is based on the "long-time occupation, possession and use" of traditional territories.

Provincial Wildlife Act is applicable to Aboriginals hunting outside the reserve by referential incorporation under s. 88 of the Indian Act.

The right to hunt is not extinguished. Hunting can happen at times outside the designated seasons.

Confirmed "fiduciary responsibility "of the Crown for Aboriginal peoples, and recognized pre-existing aboriginal rights on-reserve and off-reserve. 
Dick v. the Queen [1985] 2 S.C.R. 309

(Canadian Legal Information Institute 1985)

Sparrow [1990] 1 S.C.R. 1075 (Canadian Legal Information Institute 1990)

Van der Peet [1996] 2 S.C.R. 507 (Canadian Legal Information Institute 1996)

Delgamuukw [1997] 3 S.C.R. 1010 (Canadian Legal Information Institute 1997)

Halfway River First Nation 1999 BCCA 470 (Canadian Legal Information Institute 1999)

Kitkatla Band 2002 SCC 31, [2002] 2 S.C.R. 146 (Canadian Legal Information Institute 2002)

Haida 2004 SCC 73, [2004] 3 S.C.R. 511 (Canadian Legal Information Institute 2004a) and Taku 2004 SCC 74, [2004] 3 S.C.R. 550 (Canadian Legal Information Institute 2004b)

Marshall and Bernard 2005 SCC 43, [2005] 2 S.C.R. 220 (Canadian Legal Information Institute 2005a)

Mikisew Cree Nation 2005 SCC 69, [2005] 3 S.C.R. 388 (Canadian Legal Information Institute 2005b)

Huu-ay-aht 2005 BCSC 697 (Canadian Legal Information Institute 2005c)

Morris 2006 SCC 59, [2006] 2 S.C.R. 915

(Canadian Legal Information Institute 2006a)

Gray and Sappier 2006 SCC 54, [2006] 2 S.C. R. 686 (Canadian Legal Information Institute 2006b)

Dene Tha' 2006 FC 1354 (Canadian Legal Information Institute 2006c)

Tsilhqot'in First Nation (“Xeni”) 2007 BCSC 1700 (British Columbia Courts 2007)
The Supreme Court of Canada upheld the decision in Kruger 1976 that the Provincial Wildlife Act is applicable to Aboriginals, and that they need hunting permits, as required by the Act.

Traditional activities can be performed in a modern manner. The Crown is responsible for proving that the infringement on those rights serve a "valid legislative objective."

Used as a test as to whether the identified right constitutes an essential, integral part of Aboriginal identity.

The case distinguished between Aboriginal rights and title. Title represents a connection between the First Nation and the land. Aboriginal rights and title can be proved, and the proof can include oral sources. Infringement of Aboriginal rights can be compensated.

The Aboriginal side also has a duty to consult, and it is prohibited to impose unreasonable conditions or refuse to consult.

The Supreme Court of Canada decided that Provinces can legislate acts of destruction of heritage sites, if the acts do not affect the "core of Indianness."

These cases oblige the Crown to consult and possibly accommodate Aboriginal interests even where title has not been proven. Third parties are exempt from the duty to consult, but may be delegated some "procedural" aspects. Other cases that followed the Haida 2004 decision include: Gitanyow BCSC 2004 (Canadian Legal Information Institute 2004c), Tzeachten FC 2008 (Canadian Legal Information Institute 2008a), Klahoose BCSC 2008 (Canadian Legal Information Institute 2008b), Carrier Sekani Tribal Council BCCA 2009 (Canadian Legal Information Institute 2009a), and Kwikwetlem First Nation BCCA 2009 (Canadian Legal Information Institute 2009b).

This case sets limits to Aboriginal title: title requires evidence of exclusive and regular use of land for traditional activities. New activities are not protected by treaties. Claims of Aboriginal title are specific to the Aboriginal group and their relationship with the land.

Existing treaty rights are included in the Crown obligation to consult and accommodate Aboriginal interests.

The Supreme Court of Canada ordered the Province to consult in good faith, which does not allow for a decision made by a population-based approach. The approach based on the Nation's population used in the Forest and Range Agreements failed to account for the individual nature of the claim.

The Supreme Court of Canada decided that the Provincial Wildlife Act cannot preclude the traditional way of hunting that constitutes a treaty right.

The Supreme Court of Canada held that Aboriginal people can harvest timber on the traditional territory for domestic purposes.

The Federal Court of Appeal held that the Crown has a duty to consult with First Nations when establishing environmental and regulatory review processes. The duty to consult arises when the Crown possesses constructive and actual knowledge of an Aboriginal or treaty right that might be adversely affected by a planned activity.

This case demonstrated the type and degree of evidence sufficient to prove the existence of Aboriginal title to a large tract of land a First Nation claimed belonged to them. 
indicators and verifiers for common FSC principles and criteria. The generic FSC international standard devotes Principle 3 to the rights of Indigenous peoples. The criteria under this principle require that Indigenous peoples have control over forest management or that they have provided informed consent to delegate this control. Also required are the preservation of the resources and tenure rights of Indigenous peoples, the identification and protection of sites of significance to Indigenous peoples, and the compensation of Indigenous peoples for the use of their traditional knowledge for forest use and management. In addition to Principle 3, Principle 2 (Tenure and Use Rights and Responsibilities) requires through Criterion 2.2 that local communities that have legal or customary tenure or use rights retain control over the forest operations or delegate this control with free and informed consent. Canada's statement on free, prior, and informed consent includes refraining from a "rigid definition" of the term (Indian and Northern Affairs Canada 2005). Obtaining consent does not give Aboriginal groups a veto over what can be done on the land. The Aboriginal "consent" in the Delga muukw case (Canadian Legal Information Institute 1997) is appropriate only in cases of established rights. According to Item 48 of the Supreme Court Case (SCC) of the Haida Nation, consent is based on "...a process of balancing interests, of give and take" (Canadian Legal Information Institute 2004a). In Canada, "local communities" are often considered to be the Aboriginal communities rather than nonaboriginal communities, especially in the Boreal region. In addition, FSC Canada requires all certificate holders to comply with the International Labour Organization (ILO) Convention 169 on Indigenous and Tribal Peoples (ILO 1989; not currently ratified by Canada). However, the Canad ian FSC certification standards are not intended to switch the responsibility of consulting and accommodating from the government to the forest tenure holders. Although not all four FSC standards include the word "consult" in their requirements (the draft FSC Great Lakes-St. Laurence standard does not mention consultation in connection with Principle 3), the nature of the FSC indicators requires communication and agreements between tenure holders and relevant Aboriginal groups. Although not a mandatory requirement, written agreements are considered most appropriate by FSC and are strongly encouraged (FSC Canada 20042007).

\section{Canadian Standards Association}

The Canadian Standards Association Z809-2002follows the Canadian Council of Forest Ministers' (CCFM) application of Criteria and Indicators through Criteria and Elements. Despite pressure from Aboriginal groups such as the National Aboriginal Forestry Association (NAFA), there is no separate criterion dealing with Aboriginal people (Sherry et al. 2005). Under Criterion 6 (Accepting Society's Responsibility for Sustainable Development), two elements specifically deal with Aboriginal issues, i.e., recognition and respect for treaty rights, and respect for Aboriginal knowledge, values, and uses. Two other elements within the same criterion can also pertain to First Nations: public participation, and information sharing during decision making on forest management. The CSA standard requires demonstration that Aboriginal and treaty rights have been identified and respected (Section 7.3.4.). The requirements of Section 5.2 (c-d) also demand documented evidence that efforts were made to contact Aboriginal forest users and communities affected by or interested in forest management and to encourage them to become involved in identifying and addressing SFM values. Section 5.2 (e) further requires recognition of Aboriginal and treaty rights and consent that Aboriginal participation in the public participation process will not prejudice those rights.

\section{Sustainable Forestry Initiative}

An important requirement of both CSA and SFI st andards in the context of Aboriginal issues is compliance with all relevant legal and regulatory requirements. By having this requirement, the SFI is able to ensure that certified companies keep up with the most recent law, although the complexities associated with continuously changing laws create difficulties for both those being certified and for the auditors conducting the certifications. A further complexity is that a decision taken by a lower court can be appealed at a higher level, and so even once decisions are made in court, they may not be permanent. An exception is a decision of the Supreme Court of Canada, as shown by Weyerhaeuser's successful appeal against the Council of the Haida Nation (Canadian Legal Information Institute 2004a), in which the duty to consult was placed upon the Crown, and not upon the industry license holder. In the SFI standard, 
compliance with all relevant legislative requirements is augmented by the requirement that participants that manage forests on public land confer with affected Indigenous peoples (Performance Measure 12.4.). Participants in the standard are required to have a program that involves the development of an understanding and respect for traditional forestrelated knowledge, that enables the identification and protection of spiritual, historical, or culturally important sites, and that addresses the sustainable use of nontimber forest products of value to Indigenous peoples. This requirement was introduced in the 2005-2009 standard as part of the continual improvement process undertaken by the standard. The draft SFI 2010-2014 standard includes a specific Performance Measure (18.2), that deals with conferring with affected Indigenous peoples when managing forests on public lands. The indicator corresponding to Performance Measure 18.2 pertains to communication with the affected Indigenous peoples.

Both the SFI and CSA have obtained endorsement by the Programme for Endorsement of Forest Certification (PEFC). This is supposed to open more markets to products certified by SFI or CSA. Regarding the additional requirements that such endorsement involves, the PEFC requires adherence to several "core" ILO Conventions. However, none of those mention Aboriginal issues. International Labour Organization Conventions dealing with Aboriginal peoples (Convention 111 on Indigenous and Tribal Populations and Convention 169 on Indigenous and Tribal Peoples) are not included into the PEFC list, thus limiting the potential effects of PEFC forest certification on Aboriginal peoples.

\section{RESPONSES TO THE STANDARDS FROM ABORIGINAL GROUPS}

Given the differences among standards in addressing Aboriginal matters, it is not surprising to find that the views of Aboriginal groups about the standards also vary. For example, NAFA withdrew from participating in the CSA standard review in 2002 because of the lack of a separate Aboriginal criterion in the revised standard (NAFA 1997, Smith 2004). There is a diversity of views on forest certification, and several obstacles that prevent greater commitment to forest certification by Aboriginal communities can be identified. Similarly, a number of potential benefits that certification could bring to Aboriginal groups can be identified.

Forest certification applies to Aboriginal people in two ways: (1) certification of Aboriginal forest operations and reserve land management, and (2) the certification process for forest industry companies that have Crown tenures in traditional territories, and the impact of this on Aboriginal communities. We discuss these two aspects separately. Chain of custody certification of Aboriginal-owned forest product companies represents another way of adopting certification and is a subset of the former. However, no public data are available about the use of this type of certification by such companies in Canada.

\section{Obstacles Preventing Greater Aboriginal Commitment to Forest Certification}

Many of the concerns raised by First Nations arise from a failure of some of the certification standards to treat Aboriginal peoples as a special stakeholder (Collier et al. 2002, Stevenson and Webb 2003, Smith 2004). Even the term "stakeholder" is considered inappropriate by many Aboriginal groups, as it equates the traditional owners of a territory with other groups, such as licensees or other newcomers. The FSC standards single out Indigenous peoples and emphasize their well-being, whereas other standards do not have the same requirements related specifically to Aboriginal communities. Aboriginal views on forestry and forest management also interfere with forest certification. The terminology associated with forest certification may itself be a major barrier for those Aboriginal groups opposed to the term "forest management," as Indigenous peoples view their management as relationships, where humans are another "relation," and an integral part of the system (Parsons and Prest 2003, Stevenson and Webb 2003, Natcher et al. 2005, Sherry et al. 2005, Stevenson 2006, Wyatt 2008). In contrast, certification standards require that a specific management area should be defined in the management plans. The ecocentricity of traditional ecological knowledge, and a worldview that focuses on stewardship and connections in time and in space, present obstacles for the greater acceptance of westernized terms and instruments such as forest certification.

The methods of development and data collection for CSA indicators have also represented a dividing 
point. Traditional ecological knowledge used by Aboriginal communities cannot be easily translated into the technical indicators developed by western science, as required by the CSA (Karjala et al. 2004, Smith 2004, Sherry et al. 2005, Adam and Kneeshaw 2008, Parrotta and Agnoletti 2007, Cheveau et al. 2008). The failure to identify and incorporate traditional knowledge into a system based on western science is a common problem, and reflects the failure of western scientists to acknowledge that other knowledge systems exist (see, for example, Cajete 1999, Stevenson 2006). Although there have been problems associated with the incorporation of some of the indicators that have already been developed, this remains an active area of research, and a number of potential indicators have been developed in different parts of the world (Sherry et al. 2005). Many of these can be found in a continuously updated public resource known as the SFM Indicator Knowledge Base.

The comparison of international or Canadian Council of Forest Ministers' (CCFM) Criteria and Indicators ("C\&I") of Sustainable Forest Management with those developed by the Aboriginal community has been studied in detail (Natcher and Hickey 2002, Stevenson and Webb 2003, Karjala et al. 2004, Smith 2004, Mater 2005, Sherry et al. 2005). Much doubt has been expressed by the Canadian Aboriginal community about the effectiveness of data collection and information interpretation for CCFM and international C\&I (Karjala et al. 2004, Smith 2004, Wyatt 2008). However, not all Aboriginal groups view adoption of the C\&I as an intrusion over their traditional stewardship. In addition to the Canadian Aboriginal groups holding forest certification and adhering to the C\&I in the standards (e.g., Mistik Management Ltd., or Iissak Forest Resources Ltd.), international examples of the uptake of C\&I through adherence to FSC forest certification by Indigenous communities include three forest management certificates issued to tribal companies in the U.S. (Menominee Tribal Enterprises, Confederated Tribe of the Warm Springs Reservation, and Hoopa Valley Tribal Council), the Lake Taupo Forest Trust in New Zealand, and the Kayapó of the Bau Indigenous Territory in Brazil. Although not all Indigenous groups have maintained certification once they have obtained it (e.g., the White Mountain Apache Tribe in the U.S. was FSC-certified in 2004 but no longer holds a certificate, and the TsleilWaututh Nation in British Columbia dropped their FSC certification in 2009), some Indigenous groups do accept and adopt external C\&I.
Collier et al. (2002) also suggest that the conflict among existing legal frameworks and certification requirements may interfere with the adoption of forest certification, especially when the conflict pertains to the recognition of Aboriginal rights and title. This is a disadvantage of the highly prescriptive approach adopted by the FSC standards, and the reason why the SFI standard places emphasis on legal compliance. However, Collier et al. (2002) do emphasize that FSC Principle 3 takes the participants beyond minimum legal requirements, and this fact should not preclude adherence to certification. A much more serious obstacle that Aboriginal peoples connect with certification of their operations on reserve land is its perceived prohibitive cost and the associated increase in both the direct and indirect costs of management (Collier et al. 2002, Mater 2005, Wyatt 2008). Despite the achievements of federal program (e.g., the First N ations Forestry Program) and other partnerships (Wilson and Graham 2005, Wyatt 2008) that have been created to assist Aboriginal peoples to practise forestry, the deficit between the available resources and the capacity of the Indigenous enterprises and communities remains apparent (Collier et al. 2002, Molnar 2004, Sherry et al. 2005, Wilson and Graham 2005). Part of this is because most attempts to increase Aboriginal forestry capacity have concentrated on increasing the capacity of Aboriginal peoples to practise industrial forestry, without considering whether current industrial forestry practices are an appropriate basis to build sustainable Aboriginal communities (Stevenson and Perrault 2008).

\section{Potential Benefits from Forest Certification}

The improvement of community and Aboriginal relations has been named as one of the reasons why the forest industry chooses to certify management operations (Takahashi et al. 2003, van Kooten et al. 2005). A few sources have discussed the potential of forest certification for Aboriginal communities. Adam and Kneeshaw (2008) compare FSC-Boreal requirements with land-stewardship indicators developed by Aboriginal groups and conclude that although some overlap exists, there are also omissions: Aboriginal indicators covered all topics identified by the FSC, but a few specific Aboriginal indicators addressed ongoing access to the resource, aesthetics, and respect for Aboriginal role in resource stewardship. 
The federal First Nations Forestry Program investigated awareness and adoption of certification among Aboriginal groups, and found little interest in certification (First Nations Forestry Program 2006). A study addressing certification and Aboriginal expectations in Ontario did not find much difference between opinions of certified and noncertified respondents (Kant and Brubacher 2008). Several sources considered the FSC standards to be the most appropriate (NAFA 1996, Ozinga 2001, Collier et al. 2002, Jensens et al. 2002, Molnar 2003, Parsons and Prest 2003, Ozinga 2004, Wilson and Graham 2005). This preference is often attributed to the explicit references to First Nations in the FSC standards, and also the notion that the FSC generic standard was originally conceived for small-scale forest operations in tropical regions. Both the SFI and the CSA standards are designed primarily for large-scale industrial forestry operations and, therefore, are less appropriate for the type of operation run by most First Nations. However, it needs to be noted that few recent sources specifically discuss certification pertaining to Aboriginal people, and forest certification standards undergo continual changes. The advantages that certification of both operations on reserve land and industrial licensees operating in the traditional territories of Aboriginal peoples bring to Aboriginal communities include increased control over forest management and involvement in decision making, greater protection of nontimber forest products, potential for economic benefit and capacity building for Aboriginal communities, and an improved relationship with the forest industry (NAFA 1996, Collier et al. 2002). The advantage of chain of custody certification of Aboriginal forest products operations relate primarily to the ability to market forest products from certified land areas.

Smith (2004) indicates that forest-certification requirements supplement the governmental requirements in addressing Aboriginal rights, and that this is particularly important where there is ongoing uncertainty, e.g., in British Columbia, where treaties have yet to be established with most First Nations (Molnar 2003, Tollefson 2003, Molnar 2004).

Forest Stewardship Council Principle 3 requires that forest companies obtain Aboriginal peoples' consent over the management of land that is relevant to Aboriginal peoples. The FSC process takes the negotiations beyond the regulatory realm and provides greater opportunities for Aboriginal involvement in forest management, i.e., it requires not only consultation, but also their informed consent. The FSC-BC standard also assumes the First Nations' rights and title over land, without the litigation that has so far been a method of defining the rights and title in the absence of existing treaties (Tollefson 2003). A British Columbia Government initiative has been developed to address Aboriginal rights and title without litigation (Office of the Premier and First Nations Leadership Council 2009), but at time of writing, the proposed legislation was still under review.

Obstacles for forest certification and potential benefits from certification for Aboriginal groups are summarized in Table 2, as they apply to certifying Aboriginal operations on reserve land or to certification of tenure holders operating in the Aboriginal traditional territories.

\section{APPLICABILITY AND SCOPE OF FOREST CERTIFICATION}

Here, we briefly describe existing certified Aboriginal operations across Canada, and discuss potential benefits arising from forest certification for companies operating in traditional territory. The discussion follows the two aspects where forest certification applies to Aboriginal people: the certification of Aboriginal forest operations and reserve land management, and the certification process of non Aboriginal companies operating in Aboriginal traditional territories.

\section{Certification of Aboriginal Forestry Enterprises}

Wilson and Graham (2005) report 1,493 Aboriginal business operations related to forestry in 2002 and over 7 million $\mathrm{m}^{3}$ of timber allocated to First Nations through Crown tenures. In recent years, this figure has been increasing (Hickey and Nelson 2005). For example, in British Columbia, 7.3 million $\mathrm{m}^{3}$ had been awarded to First Nations through nonrenewable licences by 2006 , with an additional possibility of access to 3.3 million $\mathrm{m}^{3}$ annually (Parfitt 2007). Several recent agreements signed in British Columbia have given First Nations control over larger tracts of forest land than the previous corresponding reserves, in some cases including harvesting and forest protection (British Columbia 
Table 2. Potential benefits from, and obstacles to, Aboriginal commitment to forest certification.

Where applicable

\section{Benefits}

Increased control over forest management and involvement in decision making (Collier et al. 2002, National Aboriginal Forestry Association 1996)

Greater protection of non-timber forest products (Collier et al. 2002)

Potential for economic benefit and capacity building for Aboriginal communities (Collier et al. 2002, Yukon Conservation Society 2003)

Improved relationship with the forest industry (Collier et al. 2002, National Aboriginal Forestry Association 1996)

Forest certification supplements governmental requirements when there is no regulation on Aboriginal rights (National Aboriginal Forestry Association 1996, Tollefson 2003, Smith 2004).

\section{Obstacles}

The approach to Aboriginal peoples as a special stakeholder differs by standard (Collier et al. 2002, Stevenson and Webb 2003, Smith 2004).

Difficult to equalize terminology acceptable to both certification entities and Aboriginal groups (Parsons and Prest 2003, Stevenson and Webb 2003, Natcher et al. 2005, Wyatt 2008).

Differences between traditional ecological knowledge and SFM indicators in content and data collection (Karjala et al. 2004, Smith 2004, Sherry et al. 2005).

Possible interference of some certification standards with legal processes establishing Aboriginal rights and title (Collier et al. 2002, Parsons and Prest 2003).

Prohibitive cost increase in both direct and indirect cost of management (Collier et al. 2002, Mater 2005, Wyatt 2008).
Traditional territory

Traditional territory

Reserve land

Traditional territory

Traditional territory

Traditional territory

Traditional territory

Reserve land Traditional territory

Reserve land Traditional territory

Reserve land Traditional territory
Treaty Commission 2009b). However, very few examples of certification relate to First Nations' forestry enterprises in Canada. Details of the current examples of certified Aboriginal forestry are shown in Table 3. The International Organization for Standardization environmental management standard (ISO 14001) does not contain any requirements related to Aboriginal communities; however, it is sometimes used a precursor for one or more of the other certification standards, and is included in the discussion of certified companies (First Nations Forestry Program 2006).

A study undertaken in the U.S. in 2002 analyzed the views of 30 U.S. tribes on certification (Mater 2005). The study showed that $50 \%$ were willing to pursue FSC certification. Although none were ready to undergo the full SFI certification, 24\% responded that they would choose SFI if given a choice between SFI and FSC. Although valid at the time 
Table 3. Currently certified Aboriginal forest companies.

\begin{tabular}{|c|c|c|c|c|}
\hline Standard & Year of certification & $\begin{array}{l}\text { Area under } \\
\text { certificate }\end{array}$ & Type of tenure & Details \\
\hline \multicolumn{5}{|c|}{ Iisaak Forest Resources, BC } \\
\hline $\begin{array}{l}\text { FSC-International } \\
\text { Recertified to FSC- } \\
\mathrm{BC}^{\dagger}\end{array}$ & 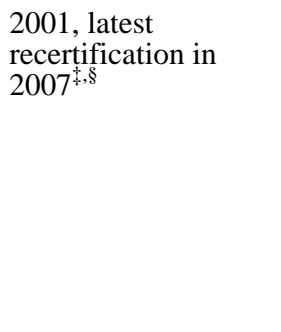 & $\begin{array}{l}87,664 \mathrm{ha} \\
\text { after } 2007 \\
76,794 \mathrm{ha}^{\ddagger},\end{array}$ & $\begin{array}{l}\text { Mix of area-based tenures. After } \\
\text { recertification in } 2007 \text {, short- } \\
\text { term tenures excluded from } \\
\text { certificate. }\end{array}$ & $\begin{array}{l}\text { Originally, } 51 \% \text { of Iisaak Forest } \\
\text { Resources were in a joint venture } \\
\text { with McMillan Bloedel Ltd., which } \\
\text { was later purchased by } \\
\text { Weyerhaeuser. Full First Nations' } \\
\text { ownership from } 2005 \text {. Harvest in } \\
2000 \text { was } 22,197 \mathrm{~m}^{3} \text {. Financial } \\
\text { stability was a major difficulty } \\
\text { associated with the } 2007 \\
\text { recertification. }\end{array}$ \\
\hline \multicolumn{5}{|c|}{ Pictou Landing First Nation, NS } \\
\hline FSC-Maritimes & $\begin{array}{l}2000, \text { latest } \\
\text { recertification in } \\
2006, \mathbb{f l}\end{array}$ & 384.5 ha & $\begin{array}{l}\text { Community forest (private and } \\
\text { reserve land) }\end{array}$ & $\begin{array}{l}\text { SLIMF." No harvest in 2004-2007. } \\
\text { Restoration of Acadian forest as } \\
\text { main objective. }{ }^{|,|}\end{array}$ \\
\hline \multicolumn{5}{|c|}{ Eel Ground First Nation, NB } \\
\hline FSC-Maritimes & 2005 & 2,853 ha & Reserve land & $\begin{array}{l}\text { SLIMF }^{\#} \text {, harvesting }<5,000 \mathrm{~m}^{3} \text { per } \\
\text { t }^{\dagger}\end{array}$ \\
\hline \multicolumn{5}{|c|}{ Mistik Management Ltd., SK } \\
\hline $\begin{array}{l}\text { ISO } 14001 \\
\text { CSA }^{\S \S} \\
\text { FSC-Boreal }^{\text {+† }}\end{array}$ & $\begin{array}{l}2004 \\
2005 \\
2007\end{array}$ & 1.8 million ha & $\begin{array}{l}\text { Forest Management Area-public } \\
\text { land, privately managed }\end{array}$ & $\begin{array}{l}50 \% \text { owned by NorSask (Meadow } \\
\text { Lake Tribal Council); } 50 \% \text { by } \\
\text { Meadow Lake Mechanical Pulp } \\
\text { Inc. Annual harvest is } 445,000 \mathrm{~m}^{3} \\
\text { of softwood and } 805,000 \mathrm{~m}^{3} \text { of } \\
\text { hardwood. }\end{array}$ \\
\hline \multicolumn{5}{|c|}{ Services Forestiers Opitciwan, QC } \\
\hline ISO 14001 & 2005 & N/A & Mix of private and public land." & $\begin{array}{l}\text { Supplies wood mainly to Scierie } \\
\text { Opitciwan sawmill, which is a joint } \\
\text { venture of Attikamek Band of } \\
\text { Opitciwan (Atikamekw Council of } \\
\text { Obedjiwan) and Abitibi- } \\
\text { Consolidated Ltd. Annual wood } \\
\text { harvest is } 120,000 \mathrm{~m}^{3} \text {. }\end{array}$ \\
\hline
\end{tabular}

\footnotetext{
$\dagger$ SmartWood Program 2005

† SmartWood Program 2007a

$\S$ SmartWood Program $2007 b$

| SmartWood Program 2006

II SmartWood Program 2008

\#Small and Low Intensity Managed Forests (Forest Stewardship Council 2002) $\dagger \dagger$ Soil Association

Woodmark 2005

†Forest Stewardship Council Canada 2004

$\S \S$ Mistik Management Ltd. 2005-2008

|| First Nations Forestry Program $2006 b$

IITINational Aboriginal Forestry Association 2000
} 
of the survey, these findings may no longer be applicable now that theAmerican Tree Farm System has achieved endorsement by the international Programme for the Endorsement of Forest Certification. It is much more applicable for smaller operations, as many Aboriginal enterprises tend to be.

A more recent study of First Nations communities in Canada revealed that Aboriginal forestry personnel are generally aware of forest certification, but consider the standards and their implementation resource-intensive (First Nations Forestry Program 2006). A few Aboriginal groups have considered FSC certification for their reserve lands as a possibility for recognizing their forest stewardship and to gain market access (e.g., Tobique First Nation 2002, Yukon Conservation Society 2003), but have not yet obtained it.

The cost of certification has been an issue for almost all certified holdings in Canada. Until now, the financial support or other resources for certification initiatives have been obtained from environmental groups, corporate partnerships, or governmental organizations. For example, Iisaak Forest Resources used to be a joint venture with MacMillan Bloedel that was later purchased by Weyerhaeuser with all MacMillan Bloedel commitments honoured before Weyerhaueser withdrew from the region (Coady 2002). Eel Ground First Nation received funding from the federal First Nations Forestry Program (2009), and Services Forestiers Opitciwan received resources from the federal Indian and Northern Affairs Canada (2004) and First Nations Forestry Program (2009). The use of federal funding to support what many would consider to be a cost of forest management is interesting, and could be interpreted as a form of domestic subsidy to specific enterprises within the forest sector, a potential issue if their products are exported to the U.S. (Zhang 2007). However, the U.S. also uses federal resources for promoting forest certification. Molnar (2004) reported the support for tribal certification from the Department of the Interior and U.S. Forest Service as a "part of the government's 'trust' responsibility to these nations." The U.S. Bureau of Indian Affairs (BIA) is expected to support marketing of third-party certified forest products from Aboriginal sources (National Congress of American Indians 2002).

Some First Nations have received aid from private sources. For example, the Tsleil-Waututh First
Nation (Inlailawatash Holdings Ltd.) obtained technical support from the charitable nonprofit organization Ecotrust Canada. Ecotrust Canada was also hired as a general manager for Iisaak Forest Resources (now 100\% Aboriginal-owned) and has provided the resources to employ Triumph Timber for operational management of the land and for maintaining the FSC certification (SmartWood Program 2005, 2007b,c). A particularly interesting dynamic is evident in these cases. Forestry economics traditionally is based on the economic yield provided by timber harvests. However, it is evident that some First Nations are successfully supplementing this income through payments from governments and environmental organizations. Should such payments be viewed as subsidies, or the successful application of payments for environmental services? $?$

Economies of scale is one reason why so few Aboriginal companies adopt the major standards (Fischer et al. 2005). Although the majority of Aboriginal tenures fall in the category of small tenures (NAFA 2007), processes exist to assist institutions with small tenures to achieve certification. Group certification offered by the FSC may be an option for operations with small and/or overlapping tenures. Another FSC option, the Sma 11 and Low Intensity Managed Forests (SLIMF) program, is offered to participants with forest tenures where timber harvesting does not happen in the industrial manner. Three out of four certified Aboriginal operations in Canada are certified to the FSC SLIMF program (Forest Stewardship Council 2002).

Several possibilities exist for woodlot-type tenures that, in the case of Aboriginal groups, apply to reserve land. There is the American Tree Farm System (ATFS) that is endorsed by the PEFC, or the newly-adopted CSA Z804-08 standard for woodlots and small-area forests.

\section{Certification Process of Companies Operating in Traditional Territory}

Almost all certified non Aboriginal forest companies in Canada conduct forest management in the traditional territories of Aboriginal peoples. Forest certification standards require consultation with, or consultation with and consent of, Aboriginal peoples affected by forest management. 
Many of the potential benefits described above can be related to cooperation with the companies working in traditional territories. Although the forest industry is often viewed as an opponent of Aboriginal groups in land-use decision making, it has been a major employer for small forestdependent communities, with over 300 communities falling into this category (Wilson and Graham 2005). These include many Aboriginal communities. Forest certification has served as a vehicle for dialog between Aboriginal peoples and the forest industry, whereby values and motives are communicated bilaterally (Collier et al. 2002, Wilson and Graham 2005). Certification has raised industry awareness of current Aboriginal issues. An improved relationship with the forest industry may lead to greater understanding and, therefore, greater respect for Aboriginal values. The analysis of forestcertification audit conditions indicated a high number of required changes in relation to Aboriginal relations (Masters et al. 2010). However, the audit conditions do not immediately translate into changes in operations: companies can obtain certification with a few years granted to fix all the audit conditions.

Recent research indicated that Aboriginal people perceived some positive effects of forest certification through improved communication, employment opportunities, and protection of relevant environmental features (Tikina et al. 2009). Kant and Brubacher (2008) also found that the level of expectation from participatory decision making was higher for Aboriginal groups with certified forests in their territory. However, the level of awareness of forest certification is not high (Kant and Brubacher 2008, Krishnaswamy et al. 2009) and the awareness is limited to forestry program staff members (First Nations Forestry Program 2006). Given that all certified companies in Canada operate in the traditional territories of different Aboriginal groups, this lack of awareness shows that forest certification only marginally influences the livelihoods of Aboriginal people.

\section{CONCLUSION}

Current law related to Aboriginal rights and title presents difficulties for certified forest companies: fulfilling forest-certification requirements to comply with the applicable law, the companies seek legal compliance, but the law is constantly changing with new court decisions or proposed legislation.
Yet, forest certification can bring a number of benefits to Aboriginal peoples. Improved communication and greater awareness of Aboriginal concerns can spring from certification processes in traditional territories. The benefits resulting from certifying an Aboriginal forest holding include the possibility of recognition of Aboriginal forest stewardship and, when combined with appropriate marketing and/or chain of custody certification, the possibility of gaining access to niche markets for timber products derived from Aboriginal lands.

The limited number of certified Aboriginal companies in Canada implies that obstacles to adoption of certification among Aboriginal entities prevail. In addition to the perceived high costs of certification that preclude the participation of small Aboriginal operations, significant resources are required to change the current situation. For many Aboriginal forestry operations, external financial support will play an important role in obtaining certification. Among other obstacles, there are differences in worldviews between western science and the traditional Aboriginal relationship with nature, and difficulties in relating traditional ecological knowledge to the criteria and indicators used by certification standards.

Future research should address these questions: "Should Aboriginal people adopt forest certification?" and "If yes, what steps can be made to stimulate adopting certification by Aboriginal groups?" Forest certification has not been a panacea for resolving issues around forest management. It has been shown that adoption of forest certification would require significant resources and education (Archer et al. 2005, Krisnaswamy et al. 2009). Forest certification must clearly become a beneficial proposition, in terms of monetary and nonmonetary benefits, before Aboriginal groups adopt it. Acknowledging Aboriginal sourcing of wood products and obtaining a price premium for them could be a possible way to change the situation. In this case, a standard should include provisions for emphasizing the Aboriginal wood origin. Or, a separate Aboriginal certification standard, different from the major certification systems currently used in Canada, could play a similar role.

In regard to forestry in Aboriginal traditional territories, the following questions present an opportunity for future research: "Is forest certification an effective mechanism to account for 
Aboriginal values in forest planning and forest management on the traditional territory?" and "How can the effectiveness of forest certification be improved in this regard?" This area of research would start with assessing Aboriginal expectations of their involvement in forest management over their traditional territory. Examples of the successful resolution of issues between Aboriginal groups and other stakeholders through forest certification would provide insights on effective and ineffective aspects of the system. Although we discovered a limited ability for forest certification to affect Aboriginal livelihoods, the development of forest-certification standards and systems does provide opportunities for greater involvement of Aboriginal people in forest certification.

Responses to this article can be read online at: http://www.ecologyandsociety.org/voll5/iss3/art33/ responses/

\section{Acknowledgments:}

We would like to acknowledge the Sustainable Forest Management Network and its financial support for the project on the effectiveness offorest certification. We extend our thanks to three anonymous reviewers for their helpful comments regarding our manuscript.

\section{LITERATURE CITED}

Adam, M. C., and D. Kneeshaw. 2008. Local level criteria and indicator frameworks: a tool used to assess Aboriginal forest ecosystem values. Forest Ecology and Management 255 (7):2024-2037.

Archer, H., R. Kozak, and D. Balsillie. 2005. The impact of forest certification labelling and advertising: an exploratory assessment of consumer purchase intent in Canada. Forestry Chronicle 81 (2):229-244.

British Columbia Courts. 2007. Tsilhqot'in Nation v. British Columbia, 2007 BCSC 1700. Supreme Court of British Columbia, Victoria, British Columbia, Canada. [online] URL: http://www.cour ts.gov.bc.ca/Jdb-txt/SC/07/17/2007BCSC1700.pdf
British Columbia Treaty Commission.2008. Aboriginal rights. British Columbia Treaty Commission, Vancouver, British Columbia, Canada. [online] URL: http://www.bctreaty.net/files/ issues rights.php

British Columbia Treaty Commission. 2009a. The issues: land and resources. British Columbia Treaty Commission, Vancouver, British Columbia, Canada. [online] URL: http://www.bctreaty.net/files/ issues landres.php.

British Columbia Treaty Commission. $2009 \mathrm{~b}$. Negotiation update: First Nations and negotiations. British Columbia Treaty Commission, Vancouver, British Columbia, Canada.[online] URL: http://ww w.bctreaty.net/files/updates.php.

Cajete, G. 1999. Native science: natural laws of interdependence. Clear Light Books, Santa Fe, New Mexico, USA.

Canadian Legal Information Institute. 1867. The Constitution Act. Federation of Law Societies of Canada, Ottawa, Ontario, Canada. [online] URL:

http://www.canlii.org/en/ca/const/const1867.html

Canadian Legal Information Institute. 1982. The Constitution Act, 1982, being Schedule B to the Canada Act 1982 (UK), 1982, c. 11. Federation of Law Societies of Canada, Ottawa, Ontario, Canada. [online] URL: http://www.canlii.org/en/ca/const/co nst1982.html.

Canadian Legal Information Institute. 1985. Indian Act, R.S.C. 1985, c. I-5. Federation of Law Societies of Canada, Ottawa, Ontario, Canada. [online] URL: http://www.canlii.org/en/ca/laws/stat/ rsc-1985-c-i-5/latest/rsc-1985-c-i-5.html.

Canadian Legal Information Institute. 1973. Calder et al. v. Attorney-General of British Columbia, [1973] S.C.R. 313. Federation of Law Societies of Canada, Ottawa, Ontario, Canada. [online] URL: http://www.canlii.org/en/ca/scc/doc/ 1973/1973canlii4/1973canlii4.html.

Canadian Legal Information Institute. 1978. Kruger and al. v. The Queen, [1978] 1 S.C.R. 104. Federation of Law Societies of Canada, Ottawa, Ontario, Canada. [online] URL: http://www.canlii. org/en/ca/scc/doc/1977/1977canlii3/1977canlii3.html. 
Canadian Legal Information Institute. 1981. R. v. Haines, 1981 CanLII 495 (BC C.A.). Federation of Law Societies of Canada, Ottawa, Ontario, Canada.[online] URL: http://www.canlii.org/en/bc/ bcca/doc/1981/1981canlii495/1981canlii495.html.

Canadian Legal Information Institute. 1984. Guerin v. The Queen, [1984] 2 S.C.R. 335. Federation of Law Societies of Canada, Ottawa, Ontario, Canada.[online] URL: http://www.canlii.o $\mathrm{rg} / \mathrm{en} / \mathrm{ca} / \mathrm{scc} / \mathrm{doc} / 1984 / 1984 \mathrm{canlii} 25 / 1984 \mathrm{canlii25.html}$.

Canadian Legal Information Institute. 1985. Dick v. The Queen, [1985] 2 S.C.R. 309. Federation of Law Societies of Canada, Ottawa, Ontario, Canada. [online] URL: http://www.canlii.org/en/ca/ scc/doc/1985/1985canlii80/1985canlii80.html.

Canadian Legal Information Institute. 1990. R. v. Sparrow, [1990] 1 S.C.R. 1075. Federation of Law Societies of Canada, Ottawa, Ontario, Canada.[online] URL: http://www.canlii.org/en/ca/ scc/doc/1990/1990canlii104/1990canlii104.html.

Canadian Legal Information Institute. 1996. R. v. Van der Peet, [1996] 2 S.C.R. 507. Federation of Law Societies of Canada, Ottawa, Ontario, Canada. [online] URL: http://www.canlii.org/en/ca/scc/doc/ 1996/1996canlii216/1996canlii216.html.

Canadian Legal Information Institute. 1997. Delgamuukw v. British Columbia, [1997] 3 S.C.R. 1010. Federation of Law Societies of Canada, Ottawa, Ontario, Canada.[online] URL: http://www. canlii.org/en/ca/scc/doc/1997/1997canlii302/1997c anlii302.html.

Canadian Legal Information Institute. 1999. Halfway River First Nation v. British Columbia (Ministry of Forests), 1999 BCCA 470. Federation of Law Societies of Canada, Ottawa, Ontario, Canada. [online] URL: http://www.canlii.org/en/bc/ bcca/doc/1999/1999bcca470/1999bcca470.html.

Canadian Legal Information Institute. 2002. Kitkatla Band v. British Columbia (Minister of Small Business, Tourism and Culture), 2002 SCC 31, [2002] 2 S.C.R. 146. Federation of Law Societies of Canada, Ottawa, Ontario, Canada. [online] URL: http://www.canlii.org/en/ca/scc/doc/ 2002/2002scc31/2002scc31.html.
Canadian Legal Information Institute. 2003. R. v. Powley, 2003 SCC 43, [2003] 2 S.C.R. 207. Federation of Law Societies of Canada, Ottawa, Ontario, Canada. [online] URL: http://www.canlii. org/en/ca/scc/doc/2003/2003scc43/2003scc43.html.

Canadian Legal Information Institute. 2004a. Haida Nation v. British Columbia (Minister of Forests), 2004 SCC 73, [2004] 3 S.C.R. 511. Federation of Law Societies of Canada, Ottawa, Ontario, Canada. [online] URL: http://www.canlii. org/en/ca/scc/doc/2004/2004scc73/2004scc73.html.

Canadian Legal Information Institute. $2004 b$. Taku River Tlingit First Nation v. British Columbia (Project Assessment Director), 2004 SCC 74, [2004] 3 S.C.R. 550. Federation of Law Societies of Canada, Ottawa, Ontario, Canada. [online] URL: http://www.canlii.org/en/ca/scc/doc/2004/2004scc7 4/2004scc74.html.

Canadian Legal Information Institute. 2004c. Gitanyow First Nation v. British Columbia (Minister of Forests), 2004 BCSC 1734. Federation of Law Societies of Canada, Ottawa, Ontario, Canada. [online] URL: http://www.canlii.org/en/bc/ bcsc/doc/2004/2004bcsc1734/2004bcsc1734.html.

Canadian Legal Information Institute. 2005a. R. v. Marshall; R. v. Bernard, 2005 SCC 43, [2005] 2 S.C.R. 220. Federation of Law Societies of Canada, Ottawa, Ontario, Canada. [online] URL: http://ww w.canlii.org/en/ca/scc/doc/2005/2005scc43/2005scc43. html.

Canadian Legal Information Institute. $2005 b$. Mikisew Cree First Nation v. Canada (Minister of Canadian Heritage), 2005 SCC 69, [2005] 3 S.C.R. 388. Federation of Law Societies of Canada, Ottawa, Ontario, Canada. [online] URL: http://ww w.canlii.org/en/ca/scc/doc/2005/2005scc69/2005scc69. html.

Canadian Legal Information Institute. 2005c. Huu-Ay-Aht First Nation et al. v. The Minister of Forests et al., 2005 BCSC 697. Federation of Law Societies of Canada, Ottawa, Ontario, Canada. [online] URL: http://www.canlii.org/en/bc/bcsc/do c/2005/2005bcsc697/2005bcsc697.html. 
Canadian Legal Information Institute. 2006a. R. v. Morris, 2006 SCC 59, [2006] 2 S.C.R. 915. Federation of Law Societies of Canada, Ottawa, Ontario, Canada. [online] URL: http://www.canlii. org/en/ca/scc/doc/2006/2006scc59/2006scc59.html

Canadian Legal Information Institute. 2006 $b$. R. v. Sappier; R. v. Gray, 2006 SCC 54, [2006] 2 S.C. R. 686. Federation of Law Societies of Canada, Ottawa, Ontario, Canada. [online] URL: http://ww w.canlii.org/en/ca/scc/doc/2006/2006scc54/2006scc54. $\underline{\mathrm{html}}$.

Canadian Legal Information Institute. 2006c. Dene Tha' First Nation v. Canada (Minister of Environment), 2006 FC 1354. Federation of Law Societies of Canada, Ottawa, Ontario, Canada. [online] URL: http://www.canlii.org/en/ca/fct/doc/ 2006/2006fc1354/2006fc1354.html.

Canadian Legal Information Institute. 2008a. Tzeachten First Nation v. Canada (Attorney General), 2008 FC 928. Federation of Law Societies of Canada, Ottawa, Ontario, Canada. [online] URL: http://www.canlii.org/en/ca/fct/doc/2008/2008fc92 8/2008fc928.html.

Canadian Legal Information Institute. $2008 b$. Klahoose First Nation v. Sunshine Coast Forest District (District Manager), 2008 BCSC 1642. Federation of Law Societies of Canada, Ottawa, Ontario, Canada. [online] URL: http://www.canlii. org/en/bc/bcsc/doc/2008/2008bcsc1642/2008bcsc1642. html.

Canadian Legal Information Institute. 2009a. Carrier Sekani Tribal Council v. British Columbia (Utilities Commission), 2009 BCCA 67. Federation of Law Societies of Canada, Ottawa, Ontario, Canada. [online] URL: http://www.canlii.org/en/bc/ bcca/doc/2009/2009bcca67/2009bcca67.html.

Canadian Legal Information Institute. 2009b. Kwikwetlem First Nation v. British Columbia (Utilities Commission), 2009 BCCA 68. Federation of Law Societies of Canada, Ottawa, Ontario, Canada. [online] URL: http://www.canlii.org/en/bc/ bcca/doc/2009/2009bcca68/2009bcca68.html.

Canadian Standards Association (CSA). 2003. Z809-02 Sustainable forest management: requirements and guidance. CSA International, Toronto, Ontario,
Canada. [online] URL: http://www.csa-international. org/product areas/forest products marking/ program documents/CAN CSA Z809-02O English. pd

Cheveau, M., L. Imbeau, P. Drapeau, and L. Bélanger. 2008. Current status and future directions of traditional ecological knowledge in forest management: a review. Forestry Chronicle $\mathbf{8 4}$ (2):231-243.

Coady, L. 2002. Iisaak: A new economic model for conservation-based forestry in coastal old growth forests, B.C. Journal of of Business Administration and Policy Analysis 27 (Annual):1701-9680.

Collier, R., B. Parfitt, and D. Woollard. 2002. A voice on the land: An Indigenous peoples' guide to forest certification in Canada. [online] URL: http:/ /www.ecotrust.ca/certification/an-indigenous-peoplesguide-forest-certification-canada.

Cooper, H. M. 1998. Synthesizing research: a guide for literature reviews. Third edition. Sage Publications, Beverly Hills and London, USA and UK.

Department of Canadian Heritage. 2004. International covenant on economic, social and cultural rights. Fifth report of Canada. Government of Canada, Ottawa, Ontario, Canada. [online] URL: http://dsp-psd.pwgsc.gc.ca/Collection/CH37-4-6-2005E. pdf.

Elias, P.D. 2004. Standards for Aboriginal cultural research in forest management planning in Canada. Project ASI-03/04-003. Canadian Model Forest Network, Calgary, Alberta, Canada.

First Nations Forestry Program. 2006. An exploration of on-reserve forest management capacity and forest certification interest in First Nations communities across Canada. Natural Resources Canada, Ottawa, Ontario, Canada. [online] URL: http://publications.gc.ca/site/eng/304839/ publication.html.

First Nations Forestry Program. 2009. First Nations Forestry Program: success stories. Natural Resources Canada and Indian and Northern Affairs Canada, Ottawa, Ontario, Canada. [online] URL: http://dsp-psd.communication.gc.ca/Collection/ Fo42-327-2005E.pdf. 
Fischer, C., F. X. Aguilar, P. Jawahar, and R. A. Sedjo. 2005. Forest certification: toward common standards? Resources for the Future, Washington, D.C., USA. [online] URL: http://www.rff.org/docu ments/RFF-DP-05-10.pdf.

Forest Stewardship Council (FSC). 2002. The SLIMF Initiative: a progress report. Increasing access to FSC certification for small and low intensity manged forests. FSC, Bonn, Germany. [online] URL: http://www.gtz.de/de/dokumente/end61-slimfs-initiative-progress-report-access-fsc-certific. pdf.

Forest Stewardship Council Australia. 2008. Draft 00 ("straw dog") of the FSC Australia National Standard-copy for public information. 7 July 2008. FSC, Melbourne, Australia. http://www. fscaustralia.org/sites/default/files/pdf/publicinfo\%20draft $\%$ 20july\%207\%2008.pdf.

Forest Stewardship Council Canada. 2004. National Boreal standard. FSC, Toronto, Ontario, Canada. [online] URL: http://www.fsccanada.org/d ocs/39146rc.on.ca/en/issues/racism/racepolicydialogue/ ah?page=SDFF.html\#fn13.

Forest Stewardship Council Canada. 2004-2007. Forest management standards. FSC, Toronto, Ontario, Canada. [online] URL: http://www.fsccan ada.org/forestmanagementstd.htm.

Hickey, C. G., and M. Nelson. 2005. Partnerships between First Nations and the forest sector: a national survey. Sustainable Forest Management Network, Edmonton, Alberta, Canada. [online] URL: http://www.sfmnetwork.ca/docs/e/SR 20040 5hickeycpart en.pdf.

Indian and Northern Affairs Canada (INAC). 2004. Backgrounder: projects funded in 20032004. INAC, Government of Canada, Gatineau, Quebec, Canada. [online] URL: http://www.ainc-in ac.gc.ca/ai/mr/nr/s-d2004/02534bbk-eng.asp.

Indian and Northern Affairs Canada. 2005. Statement - legal commentary on the concept of free, prior and informed consent. Statement issued in Geneva, Switzerland, 20 July 2005. INAC, Government of Canada, Gatineau, Quebec, Canada. [online] URL: http://www.ainc-inac.gc.ca/ap/ia/stmt/ unp/05/pop/lgl-eng.asp.
International Labour Organization (ILO). 1989. C169 Indigenous and Tribal Peoples Convention. 27 June 1989. ILO, Geneva, Switzerland. http://ww w.ilo.org/ilolex/cgi-lex/convde.pl?C169.

International Tropical Timber Organization (ITTO). 2005. Status of tropical forest management 2005. ITTO, Nishi-ku, Yokohama, Japan. [online] URL: http://www.itto.int/en/sfm detail/id=1801.

Jensens, J.-W., E. Kretzmann, and S. Harrington. 2002. Forest certification on tribal lands: a resource manual for Native American forest management operations and forest product enterprises. Second edition. First Nations Development Institute, Fredericksburg, Virginia, USA. [online] URL: http://www.firstnations.org/Pu blications/ForestryManualAll.pdf.

Kant, S., and D. Brubacher. 2008. Aboriginal expectations and perceived effectiveness of forest management practices and forest certification in Ontario. Forestry Chronicle 84 (3):378-391.

Karjala, M. K., E. E. Sherry, and S. M. Dewhurst. 2004. Criteria and indicators for sustainable forest planning: a framework for recording Aboriginal resource and social values. Forest Policy and Economics 6(2):95-110.

Krishnaswamy, A., L. Joseph, E. Simmons, G. Thomas, and J. Passmore. 2009. First Nations, forestry, and natural resources information needs in British Columbia. [online] URL: http://www.for rex.org/publications/other/FileReports/fr09-01.pdf

Masters, M., A. Tikina, and B. Larson. 2010. Forest certification audit results as potential changes in forest management in Canada. The Forestry Chronicle 86(4). [online] URL: http://www.fsccana da.org/docs/julyaug2010 forestrychronicle comparison. pdf.

Mater, C. M. 2005. The Montreal process criteria and indicators and tribal views on forest health and sustainability: is there a match? Evergreen Winter 2005-2006:11-16.

McGregor, D. 2009. Aboriginal/non-Aboriginal relations and sustainable forest management in Canada: the influence of the Royal Commission on Aboriginal Peoples. Journal of Environmental Management, in press. 
Mistik Management Ltd. 2005-2008. CSA Z809-02 Forest certification documents. Meadow Lake, Saskatchewan, Canada. [online] URL: http:// www.mistik.ca/csa.htm.

Molnar, A. 2003. Forest certification and communities: looking forward to the next decade. Forest Trends, Washington, D.C., USA.

Molnar, A. 2004. Forest certification and communities. International Forestry Review 6 (2):173-180.

Natcher, D. C., S. Davis, and C. G. Hickey. 2005. Co-management: managing relationships, not resources. Human Organization 64(3):40-251.

Natcher, D. C., and C. G. Hickey. 2002. Putting the community back into community-based resource management: a criteria and indicators approach to sustainability. Human Organization 61 (4):350-363.

National Aboriginal Forestry Association (NAFA). 1996. Assessment of the need for Aboriginal compliance with sustainable forest management and forest product certification systems. Golden Lake, Ontario, Canada. [online] URL: http://www.nafaforestry.org/cert/.

National Aboriginal Forestry Association. 1997. An Aboriginal criterion for sustainable forest management. Golden Lake, Ontario, Canada. [online] URL: http://www.nafaforestry.org/criterion/

National Aboriginal Forestry Association. 2000. Aboriginal-forest sector partnerships: lessons for future collaboration. Golden Lake, Ontario, Canada.[online] URL: http://www.nafaforestry.org/ nafaiog/.

National Aboriginal Forestry Association. 2007. Second report on First Nation-held forest tenures in Canada. Golden Lake, Ontario, Canada.

National Congress of American Indians (NCAI). 2002. Resolution \#BIS-02-020. NCAI, Washington, D.C., USA. [online] URL: http://www.ncai.org/ncai/ data/midyear2002/BIS-02-020.pdf.

O'Callaghan, K., K. Grist, and D. Westgeest. 2008. Tzeachten and Gitanyow: update on the duty to consult. Aboriginal Law Bulletin. Fasken Martineau DuMoulin LLP, Vancouver, British Columbia, Canada. [online] URL: http://www.fask en.com/files/Publication/ad420e9a-74b8-4170-9cae -187c4189794a/Presentation/PublicationAttachment/ ecfe389c-5618-4cc0-8c43-23fe726d6403/Aboriginal\% 20 October \%202008 en.pdf.

Office of the Premier and First Nations Leadership Council. 2009. Statement on Recognition and Reconciliation Act. 20090TP0049-000366. Ministry of Aboriginal Relations and Reconciliation, Government of British Columbia, Victoria, BC, Canada. [online] URL: http://www.fn s.bc.ca/pdf/Statement RecognitionReconciliationAct. pdf.

Office of the United Nations High Commissioner for Human Rights (OHCHR). 1969. International Convention on the Elimination of All Forms of Racial Discrimination. OHCHR, Geneva, Switzerland. [online] URL: http://www2.ohchr.org/english/law/ cerd.htm

Office of the United Nations High Commissioner for Human Rights. 1976a. International Covenant on Civil and Political Rights. OHCHR, Geneva, Switzerland.[online] URL: http://www2.ohchr.org/ english/law/ccpr.htm.

Office of the United Nations High Commissioner for Human Rights. 1976b. International Covenant on Economic, Social and Cultural Rights. OHCHR, Geneva, Switzerland. [online] URL: http://www2.0 hchr.org/english/law/cescr.htm.

Ontario Human Rights Commission. 2001. An intersectional approach to discrimination: addressing multiple grounds in human rights claims. Ontario Human Rights Commission, Toronto, Ontario, Canada.[online] URL: http://www.ohrc.on.ca/en/re sources/discussion consultation/DissIntersectionalityFtnts/ pdf.

Ozinga, S. 2001. Behind the logo: an environmental and social assessment of forest certification schemes. FERN, Brussels, Belgium. [online] URL: http://www.fern.org/node/532.

Ozinga, S. 2004. Footprints in the forest: current practice and future challenges in forest certification. FERN, Brussels, Belgium. [online] URL: http://www.fern.org/pubs/reports/footprints.pdf 
Parfitt, B. 2007. True partners: charting a new deal for BC, First Nations and the forests we share. Canadian Centre for Policy Alternatives, Vancouver, British Columbia, Canada. [online] URL: http://www.policyalternatives.ca/sites/default/ files/uploads/publications/BC Office Pubs/bc 2007/ bc truepartners.pdf.

Parrotta, J. A., and M. Agnoletti. 2007. Traditional forest knowledge: challenges and opportunities. Forest Ecology and Management 249 (1-2):1-4.

Parsons, R., and G. Prest. 2003. Aboriginal forestry in Canada. The Forestry Chronicle 79 (4):779-784.

Resources for Aboriginal Studies. 2006. Rex v. Jim 26 C.C.C. 236 [1915]. University of Saskatchewan Libraries, Saskatoon, Saskatchewan, Canada. [online] URL: http://library2.usask.ca/native/ cnlc/vol04/328.html?q=native/cnlc/vol04/328.html

Secretariat of the Convention on Biological Diversity (CBD). 1993. Convention on Biological Diversity. CBD, Montreal, Quebec, Canada. [online] URL: http://www.cbd.int/convention/conv ention.shtml.

Sherry, E., R. Halseth, G. Fondahl, M. Karjala, and B. Leon. 2005. Local-level criteria and indicators: an Aboriginal perspective on sustainable forest management. Forestry 78(5):513-539.

SmartWood Program. 2004. Forest management public summary for Inlailawatash Holdings Ltd. Rainforest Alliance, New York, New York, USA. [online] URL: http://http://www.rainforest-alliance. org/forestry/documents/inlailawatash.pdf.

SmartWood Program. 2005. Forest management public summary for Iisaak Forest Resources Ltd. Rainforest Alliance, New York, New York, USA. [online] URL: http://www.rainforest-alliance.org/fo restry/documents/iisaak.pdf.

SmartWood Program. 2006. Forest management public summary for Pictou Landing First Nation. Rainforest Alliance, New York, New York, USA. [online] URL: http://www.rainforest-alliance.org/fo restry/documents/pictou.pdf.
SmartWood Program. 2007a. Forest management certification assessment report for: Iisaak Forest Resources Ltd. in Ucluelet, British Columbia. Rainforest Alliance, New York, New York, USA. [online] URL: http://www.rainforest-alliance.org/fo restry/documents/iisaakforestfmpubsum07.pdf.

SmartWood Program. 2007b. Forest management precondition verification audit report for: Iisaak Forest Resources Ltd in Ucluelet, British Columbia. Rainforest Alliance, New York, New York, USA. [online] URL: http://www.rainforest-alliance.org/fo restry/documents/iisaakforestfmprecondverifaudit07. pdf.

SmartWood Program. 2008. Forest management 2008 annual audit report for Pictou Landing First Nation in Truro, Nova Scotia. Rainforest Alliance, New York, New York, USA. [online] URL: http:// www.rainforest-alliance.org/forestry/documents/ pictoupubsum08.pdf.

Smith, P. 1998. Aboriginal and treaty rights and Aboriginal participation: essential elements of sustainable forest management.Forestry Chronicle 74(3):327-333.

Smith, P. 2004. Inclusion before streamlining: the status of data collection on Aboriginal issues for sustainable forest management in Canada. Pages 94-104 in J. L. Innes, G. M. Hickey, and B. Wilson, editors. International perspectives on streamlining local-level information for sustainable forest management. Canadian Forest Service Pacific Forestry Centre, Victoria, British Columbia, Canada.

Stevenson, M. G. 2006. The possibility of difference: rethinking co-management. Human Organization 65(2):167-181.

Stevenson, M. G., and P. Perrault. 2008. Capacity for what? Capacity for whom? Aboriginal capacity and Canada's forest sector. Sustainable Forest Management Network, Edmonton, Alberta, Canada. [online] URL: http://www.sfmnetwork.ca/ docs/e/Stevenson Perrault Capacity Synthesis.pdf

Stevenson, M. G., and J. Webb. 2003. Just another stakeholder? First Nations and sustainable forest management in Canada's Boreal forest. Pages 65112 in P. J Burton, C. Messier, D. M. Smith, W. I. Adamowicz, P. J. Burton, C. Messier, D. W. Smith, 
and W. L. Adamowic, editors. Towards the sustainable management of the Boreal forest. NRC Research Press, Ottawa, Ontario, Canada.

Supreme Court of British Columbia (SCBC). 2007. Tsilhqot' in Nation v. British Columbia, 2007 BCSC 1700. SCBC, Victoria, British Columbia, Canada. [online] URL: http://www.courts.gov.bc.ca/ Jdb-txt/SC/07/17/2007BCSC1700.pdf.

Takahashi, T., C. G. van Kooten, and I. Vertinsky. 2003. Why might forest companies certify? Results from a Canadian survey. International Forestry Review 5(4):1465-5489.

Tikina, A. V., R. A. Kozak, J. L. Innes, J. Chen, R. L. Trosper, P. N. Duinker, and B. C. Larson. 2009. Stakeholder perspectives on forest certification in Canada. Electronic lecture, 19 August 2009, Canadian Institute of Forestry, Mattawa, Ontario, Canada.

Tobique First Nation. 2002. Joint project between Sustainable Communities Initiative- Natural Resources Canada and Tobique First Nation. Tobique First Nation, New Brunswick, Canada. [online] URL: http://ess.nrcan.gc.ca/2002 2006/sci/ pdf/98prs.pdf.

Tollefson, C. 2003. Indigenous rights and forest certification in British Columbia. Pages 93-118 in J. Kirton and V. MacLaren, editors. Hard choices, soft law: voluntary standards in global trade, environment and social governance. Ashgate Press, Aldershot, New Mexico USA.

Tollefson, C., F. Gale, and D. Haley. 2008. Setting the standard: certification, governance and the Forest Stewardship Council. University of British Columbia Press, Vancouver, British Columbia, Canada.

United Nations Department of Economic and Social Affairs (UN DESA). 2007. United Nations Declaration on the Rights of Indigenous Peoples. UN DESA, Division for Social Policy and Development, New York, New York, USA. [online] URL: http://www.un.org/esa/socdev/unpfii/en/drip. $\underline{\text { html. }}$

van Kooten, G. C., H. W. Nelson, and I. Vertinsky. 2005. Certification of sustainable forest management practices: a global perspective on why countries certify. Forest Policy and Economics 7(6):857-867.
Virtual Law Office. 1998. The Royal Proclamation of October 7, 1763. Toronto, Ontario, Canada. [online] URL: http://www.bloorstreet.com/200block/ rp1763.htm.

Wilson, J., and J. Graham. 2005. Relationships between First Nations and the forest industry: the legal and policy context. Institute on Governance, Ottawa, Ontario, Canada. [online] URL: http://iog. ca/en/publications/relationships-between-first-nationsand-forest-industry-legal-and-policy-context.

Soil Association Woodmark. 2005. Woodmark SLIMF forest certification report: Eel Ground First Nation. Woodmark, Bristol, UK.

Wyatt, S. 2008. First Nations, forest lands and "Aboriginal forestry" in Canada: from exclusion to comanagement and beyond. Canadian Journal of Forest Research 38:171-180. [online] URL: http:// article.pubs.nrc-cnrc.gc.ca/RPAS/rpv?hm=

HInit\&calyLang=eng \&journal=cjfr $\&$ volume $=38 \&$ afpf $=$ x07-214.pdf.

Yukon Conservation Society. 2003. National Boreal forest certification standards endorsed. Whitehorse, Yukon, Canada. [online] URL: http:// www.yukonconservation.org/library/newsletters/ spring2004.pdf.

Zhang,D. 2007. The softwood lumber war: politics, economics, and the long U.S.-Canadian trade dispute. Resources For the Future Press, Washington, D.C., USA. 